\title{
Relationships between nucleic acid levels and egg production rates in Acartia bifilosa: implications for growth assessment of copepods in situ
}

\author{
Elena Gorokhova* \\ Department of Systems Ecology, Stockholm University, 10691 Stockholm, Sweden
}

\begin{abstract}
To evaluate the applicability of RNA-based indices in copepod growth assessment, concentrations of nucleic acids in Acartia bifilosa were calibrated against growth rates estimated via egg production experiments, and the relationships between levels of RNA, DNA, and the RNA:DNA ratio and growth rates were examined. Furthermore, to investigate effects of temperature and food availability on the relationships between weight-specific fecundity and nucleic acid levels, incubations were carried out at 9 and $16^{\circ} \mathrm{C}$, each at 3 food concentrations. There were positive relationships between nucleic acid concentrations and their ratios and weight-specific egg production rates. Overall, RNA concentration was the best predictor of specific growth rate. No correlations between either of the measured variables and female body size were observed. When egg production was elevated by manipulating the feeding regime, RNA concentration and the RNA:DNA ratio increased in concert. Neither growth nor RNA indices were significantly affected by temperature, while a significant increase in DNA concentrations was observed at high food levels and low temperatures. The lack of temperature dependence in RNA-growth relationships allows their direct application for in situ growth estimates in summer populations of A. bifilosa in the northern Baltic Proper.
\end{abstract}

KEY WORDS: Nucleic acid concentrations - RNA:DNA - Growth rate - Egg production . Weight-specific fecundity $\cdot$ Baltic $\cdot$ Acartia bifilosa

Resale or republication not permitted without written consent of the publisher

\section{INTRODUCTION}

The lack of appropriate methodology for measuring site- and time-specific growth rates remains the greatest obstacle to estimating in situ zooplankton production (Poulet et al. 1995). In copepods, which are ecological key species in marine, and often in freshwater, ecosystems, production consists primarily of juvenile growth and adult egg production. Direct measurement of egg production is currently most used to estimate copepod growth (Poulet et al. 1995). This method is highly sensitive to changes in environmental variables (Saiz et al. 1997), and has the advantage of site- and time-specific estimates of production. However, egg production experiments are both time and labor consuming. Moreover, the risk of introducing artifacts due to the handling and use of various anesthetics is high, and bottle-effects are unavoidable (Miller et al. 1984). Consequently, there is still no definitive routine method for measuring copepod growth in situ (Poulet et al. 1995), and the search for new analytical tools and techniques for growth assessment is a significant issue for nearly all plankton biologists.

Since Sutcliffe $(1965,1970)$ suggested that growth could be estimated from the RNA content in small crustaceans, nucleic acid measures have generated increasing interest and have come to be recognized as a promising biochemical tool for evaluating growth and nutritional conditions in a variety of species. Accumulating research suggests a characteristic biochemical signature of rapid organism growth, manifested in elevated RNA concentrations, which is driven by the fundamental association of rapid growth with ribosomal RNA (Elser et al. 2000). Several studies have 
tested the applicability of nucleic acid analysis for growth rate assessment using RNA concentrations (Dagg \& Littlepage 1972, Ota \& Landry 1984, Båmstedt \& Skjodal 1980) or RNA:DNA values (Wagner et al. 1998, 2001) of mono- or multispecies zooplankton samples. Although most of the early studies focused on using RNA:DNA ratios as an index of nutritional condition (Wagner et al. 1998), a calibration of zooplankton growth rates against nucleic acid content has also been attempted, and linear relationships have been found between growth rate and RNA content (and/or RNA:DNA ratio) for various species of marine copepods (Nakata et al. 1994, Saiz et al. 1998, Wagner et al. 2001) and freshwater cladocerans (Vrede et al. 2002). In some cases, however, the relationship between RNA content and growth rate has been found to lack sufficient predictability (Dagg \& Littlepage 1972, Ota \& Landry 1984). Of great interest, therefore, are the 'rules' used to estimate growth from nucleic acid measurements, and these need to be defined. For example, it has been shown that temperature influences the relationship between RNA and growth in copepods (Saiz et al. 1998, Wagner et al. 2001) and lobsters (Juinio et al. 1992), while a correlation was found between body size and the RNA:protein ratio in squid (Moltschaniwskyj \& Jackson 2000), and between developmental stage and RNA-based indices in copepods (Wagner et al. 1998, 2001) and daphniids (Gorokhova \& Kyle 2002). Thus, RNA-growth relationships need to be thoroughly evaluated and calibrated with independent estimates of growth rates, also in relation to biotic and ambient environmental conditions. In the case of copepods, growth rates determined via egg production experiments may serve as such independent measures.

In the northern Baltic Proper, the copepods Acartia bifilosa Giesbrecht and A. longiremis Lilljeborg constitute 22 to $44 \%$ of the total zooplankton biomass (Hansson et al. 1990, Viitasalo 1992). Of these 2 species, A. bifilosa dominates, especially in the upper mixed layer, and constitutes ca. $80 \%$ of the Acartia biomass in the coastal areas of the Stockholm Archipelago (Adrian et al. 1999). It is also one of the main prey species for fish (Hansson et al. 1990); therefore, A. bifilosa is considered to be a key species for zooplankton production in this region, and availability of rapid-yetsensitive methods to measure its growth would allow us to address many interesting ecological questions.

The primary objective of this study was to evaluate the applicability of RNA-based indices to assess copepod growth by examining: (1) relationships between reproductive growth rates and RNA-DNA concentrations and RNA:DNA ratios in Acartia bifilosa, and (2) the effects of temperature and food availability on these relationships.

\section{MATERIALS AND METHODS}

Collection sites and methods. Egg production rates of Acartia bifilosa were estimated from shipboard incubations carried out in August 1998 during the second BASYS (Baltic Sea System Study) cruise in the eastern Gotland basin of the northern Baltic Proper (Fig. 1). Data on environmental conditions were obtained from simultaneous measurements during the cruise, according to standard protocol of the Baltic Monitoring Programme (HELCOM 1988). Copepods were obtained either from slow vertical or drift tows made with a $90 \mu \mathrm{m}$ WP-2 plankton net, or with a $50 \mathrm{l}$ water bottle within the upper 10 to $15 \mathrm{~m}$. The zooplankton were transferred into a plastic insulated container with ambient seawater and sorted within an hour. Copepods were gently removed from this container using a sieve, washed into a petri dish, and sorted under a dissecting microscope with a wide-mouthed pipette.

Egg production under ambient conditions. Groups of 3 to 5 adult females of Acartia bifilosa, which is a free-spawning species, were incubated in either 1 or $0.3 \mathrm{l}$ bottles for 24 to $28 \mathrm{~h}$ at the ambient water temperature $\left(15.6\right.$ to $\left.17.8^{\circ} \mathrm{C}\right)$. Surface water was filtered through a $60 \mu \mathrm{m}$ net and used as an experimental medium. The $1 \mathrm{l}$ bottles were placed in a plankton wheel, turning at a speed of $0.5 \mathrm{rpm}$, and the 0.31 bot-

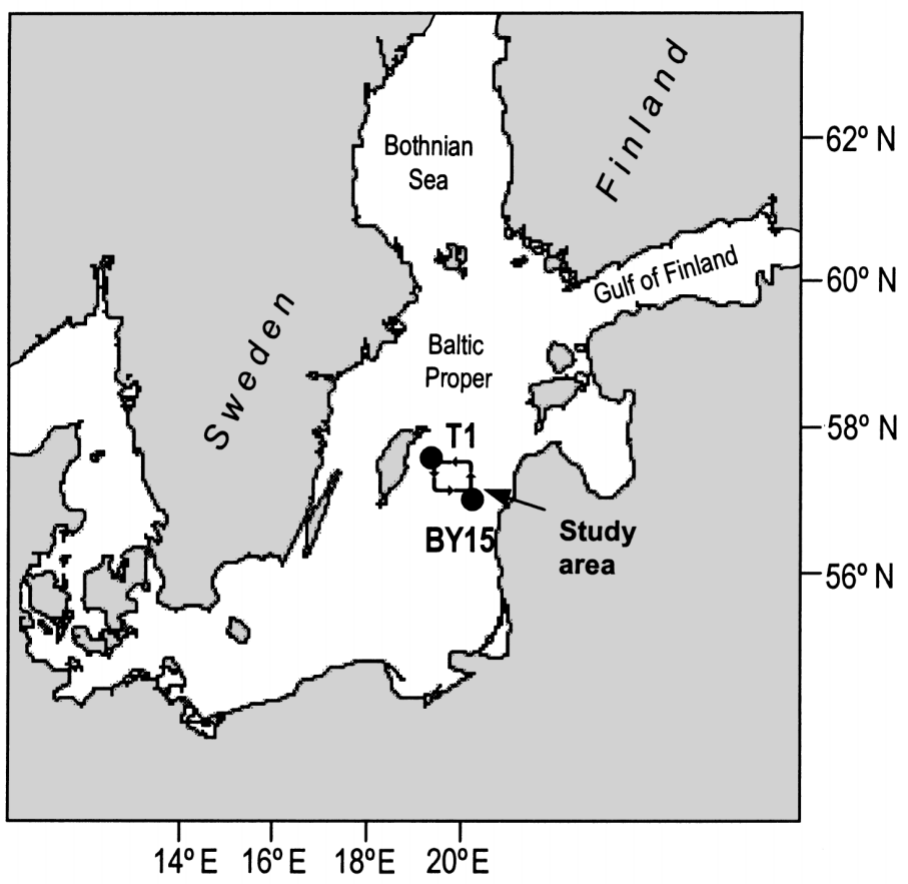

Fig. 1. Study area: samples were taken during a scientific cruise with RV 'Baltica' in August 1998 in the northern Baltic Proper. Most of the experimental animals were collected at Stns T1 $\left(57^{\circ} 36^{\prime} \mathrm{N} 19^{\circ} 21^{\prime} \mathrm{E}\right.$, bottom depth $\left.36 \mathrm{~m}\right)$ and BY15 $\left(57^{\circ} 16^{\prime} \mathrm{N} 20^{\circ} 05^{\prime} \mathrm{E}, 114 \mathrm{~m}\right)$ 
tles were incubated in a covered $50 \mathrm{l}$ plastic container, through which surface seawater was pumped continuously. The ship's motion was assumed to be sufficient for keeping phytoplankton in suspension. Although none of the experimental incubation bottles had a screen to prevent females from ingesting their eggs, the low density of females was assumed to minimize the possibility of egg cannibalism (Laabir et al. 1995), and no empty or damaged eggs were observed. At the end of incubation, the contents of each incubation bottle were poured through a $35 \mu \mathrm{m}$ submerged sieve, and eggs and nauplii were counted under a dissecting microscope. Females were removed, rinsed with $0.2 \mu \mathrm{m}$ filtered surface seawater, and their prosome length (PL, $\mathrm{mm}$ ) was measured under a microscope equipped with a micrometer eyepiece. They were then transferred into $1.5 \mathrm{ml}$ Eppendorf tubes (1 per experimental replicate, i.e. a group of 3 to 5 ind. per tube) and stored at $-80^{\circ} \mathrm{C}$ until nucleic acid analysis.

Effects of temperature and food on egg production and nucleic acid levels. To study effects of temperature $(\mathrm{T})$ and food availability (F) on growth rates and nucleic acid concentrations, a $2 \times 3$ factorial experimental design was used ( $\mathrm{T} \times \mathrm{F}$ experiment hereafter). In this experiment, 3 females of Acartia bifilosa were placed in each of 18 bottles $(0.3 \mathrm{l})$. The bottles were incubated at 9 or $16^{\circ} \mathrm{C}$ ( 9 bottles at each temperature) and 3 alternative feeding regimes (high, medium, and low; 3 replicates for each feeding regime and temperature). To create a gradient in food availability, prescreened $(60 \mu \mathrm{m})$ ambient water (referred as 'medium food level'; chl a $\sim 2.4 \mathrm{mg} \mathrm{m}^{-3}$, particulate organic carbon [POC] $\sim 640 \mathrm{mg} \mathrm{C} \mathrm{m}^{-3}$ ) was either 5-fold diluted ('low food level'; chl a $\sim 0.5 \mathrm{mg} \mathrm{m}^{-3}$,) or 5 -fold concentrated ('high food level'; chl $a \sim 12.0 \mathrm{mg} \mathrm{m}^{-3}$ ) by tension-flow filtration. All experimental animals were adapted to temperature and feeding conditions by incubating them in the respective temperature and food combination for $\sim 32$ to $42 \mathrm{~h}$ prior to the experiment. A few males were added to containers with females during the adaptation period to ensure insemination. Egg production measurements and preservation of the experimental animals were conducted in the same way as in experiments under ambient conditions.

Growth estimates. Egg production rates (EPR, eggs female ${ }^{-1} \mathrm{~d}^{-1}$ ) were calculated as:

$$
\mathrm{EPR}=\frac{E+N}{F} \times \frac{1}{t}
$$

where $E$ is the number of eggs at the end of incubation, $N$ is the number of hatched nauplii, $F$ is the number of incubated females, and $t$ is the duration of the experiment (d). Weight-specific egg production rates $\left(\right.$ SEPR, $\left.\mathrm{d}^{-1}\right)$ of females were calculated as:

$$
\mathrm{SEPR}=\mathrm{EPR} \times \frac{W_{\mathrm{e}}}{W_{\mathrm{f}}}
$$

where $W_{\mathrm{f}}$ and $W_{\mathrm{e}}$ are female and egg weights as carbon. Egg weight for Acartia bifilosa was estimated to be $0.04 \mu \mathrm{g} \mathrm{C}$ egg $^{-1}$, based on the measured average egg diameter of $83 \mu \mathrm{m}$, and assuming a density of

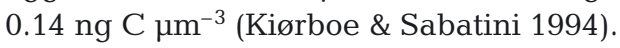

The carbon content of a female was estimated from the length-carbon regression:

$$
W=\mathrm{e}^{3.793 \text { PL-2.285 }}
$$

where $W$ is body carbon content $(\mu \mathrm{g})$ and PL is prosome length $(\mathrm{mm})$. This regression was obtained for Acartia bifilosa within the same size range, and sampled in late summer at coastal stations in Storfjärden (Gulf of Finland; Viitasalo et al. 1995).

Nucleic acid analysis. Nucleic acids were quantified according Wagner et al. (1998), with some modifications; measured RNA and DNA concentrations were expressed as $\mu \mathrm{g} \mathrm{mg} \mathrm{C}^{-1}$ using copepod individual carbon weights (Eq. 3).

Reagents: RNA (Type III: from Bakers Yeast, Sigma, cat. \# R-7125); DNA (calf thymus, Sigma, cat. \# D-1501); RNase, DNase-free (Boehringer Mannheim, cat. \# 1579681), 50 Kunitz $\mathrm{U} \mathrm{ml}^{-1}$ in TE buffer; N-lauroysarcosine (sarcosyl, Sigma, cat. \# L-5125); ethidium bromide, $\mathrm{EtBr}$, nuclease-free (Fisher Scientific); sterile water was used in all solutions.

Buffers: TE buffer; extraction buffer: $1 \% \mathrm{w} / \mathrm{v}$ sarcosyl in TE buffer; standard buffer: $0.25 \%$ sarcosyl in TE buffer.

Standards: RNA and DNA standard sets were prepared from frozen $\left(-80^{\circ} \mathrm{C}\right)$, aliquoted stock. Working solutions were diluted in Standard buffer in concentrations ranging from 0.2 to $8.0 \mu \mathrm{g} \mathrm{ml}^{-1}$ for RNA and from 0.2 to $6.0 \mu \mathrm{g} \mathrm{ml}^{-1}$ for DNA. The standard sets were aliquoted and stored at $-80^{\circ} \mathrm{C}$ until analysis.

Controls: Negative controls containing all chemicals but no copepods were included in every set of samples and processed in the same way. Positive controls were prepared as follows: ca. $0.5 \mathrm{mg}$ of fresh organisms (all stages, a mixture of species retained on $500 \mu \mathrm{m}$ net) were crushed in $1 \mathrm{ml}$ of water and centrifuged; supernatant was aliquoted, stored at $-80^{\circ} \mathrm{C}$, and a $10 \mu \mathrm{l}$ aliquot was used as a positive control sample with each set of experimental samples.

Extraction procedure: Extraction buffer $(200 \mu \mathrm{l})$ was added directly to the tubes containing frozen copepods and samples were shaken at room temperature for $2 \mathrm{~h}$. After extraction, TE buffer was added (600 $\mu \mathrm{l})$, samples were shaken again for $15 \mathrm{~min}$ and centrifuged for $1 \mathrm{~min}$ at $7500 \mathrm{rpm}$.

Fluorometric determinations: Fluorescence measurements were conducted using a Fluoroscan II fluorometer (Labsystems, microplate reader, filters: $544 \mathrm{~nm}$ 
for excitation and $590 \mathrm{~nm}$ for emission) and black solid flat-bottom COMBO microplates (Labsystems, cat. \# 9502067). Each plate included: (1) extracted samples and controls, 6 replicates, $80 \mu \mathrm{l}$ well $^{-1}$; (2) RNA and DNA standards, 2 to 4 replicates, $80 \mu \mathrm{l}$ well ${ }^{-1}$. Half of the replicates of each sample/control were designated for RNA determination (hereafter RNA samples/ controls) and half for DNA determination (hereafter DNA samples/controls). DNA samples, DNA controls, and DNA standards received $5 \mu \mathrm{l}$ well $^{-1}$ of RNase followed by $25 \mathrm{~min}$ incubation at $37^{\circ} \mathrm{C}$. At the end of the incubation, $80 \mu \mathrm{l}$ well $^{-1}$ of EtBr were added to all wells and the plate was incubated for another $5 \mathrm{~min}$ at room temperature in darkness. The plate was then scanned with $0.5 \mathrm{~s}$ well-measurement time, 10 measurements per well. Total DNA was calculated based on the DNA-EtBr standard curve. Total RNA was estimated by calculating the difference between RNA and DNA sample fluorescence. From this difference, RNA concentrations in the samples were calculated based on the RNA-EtBr standard curve. Recoveries were determined by spiking 6 samples (3 for RNA and 3 for DNA) of positive controls. RNA and DNA standard stocks were added to this homogenate at concentrations of half the expected values for the homogenate. The final yields of RNA and DNA recovery were $94.1 \pm 4.3$ and $93.3 \pm 5.8 \%$, respectively. Accordingly, the concentrations in the samples were corrected for percent recovery of internal standards.

Statistics. Statistical tests were conducted with GraphPad Prism 3.03 (GraphPad Software). Unless specified otherwise, data are presented as means \pm SD. When comparing 2 groups, an unpaired $t$-test was applied followed by an F-test to compare variances. The effects of temperature and food levels were examined by 2-way ANOVA. Data were tested for homogeneity of variances using Bartlett's test. Linear regressions were fitted by the least-squares method; ANCOVA was used to compare slopes and intercepts of regression lines. To determine whether the data differ significantly from a straight line, a runs test was applied. In all cases significance was accepted when $\mathrm{p}<0.05$.

\section{RESULTS}

\section{Environmental and feeding conditions}

Due to strong winds and low temperatures in the summer of 1998, the mixing layer was very uniform, with temperatures between 14 and $17^{\circ} \mathrm{C}$. The thermocline was situated around 15 to $17 \mathrm{~m}$ depth. Concentrations of chl $a$, particulate organic carbon (POC) and particulate organic nitrogen (PON) were fairly homogenous in the mixed layer. The chl a concentration was on average $2.4 \mathrm{mg} \mathrm{m}^{-3}$, mean standing stocks of POC and PON were $640 \mathrm{mg} \mathrm{C} \mathrm{m}^{-3}$ and $80 \mathrm{mg} \mathrm{N} \mathrm{m}^{-3}$, respectively. Particulate phosphorus in the mixed layer ranged from 6 to $11 \mathrm{mg} \mathrm{P} \mathrm{m}^{-3}$ (Olesen et al. 1999). The phytoplankton community was dominated by cyanobacteria and nanoflagellates $<15 \mu \mathrm{m}$. Filamentous cyanobacteria (>90 $\mu \mathrm{m}_{i}$ Aphanizomenon sp. and Nodularia spumigena) and picocyanobacteria (3 to $10 \mu \mathrm{m}$; mostly compact and loose colonies of Cyanodiction imperfectum, C. planctonicum, and Cyanonephron styloides) exceeded $70 \%$ of the phytoplankton biomass in the top $10 \mathrm{~m}$ of the water column, often with picocyanobacteria as the single most important group. The total phytoplankton biomass averaged $67.5 \mathrm{mg} \mathrm{C} \mathrm{m}^{-3}$ or $7.45 \mathrm{~g} \mathrm{C} \mathrm{m}^{-2}$ over the entire water column (S. Hajdu \& H. Höglander, Stockholm University, pers. comm.).

\section{Variability of EPR and SEPR}

In the experiments with incubation in ambient water, EPR and SEPR averaged 8.3 and 0.28 eggs female ${ }^{-1}$ $\mathrm{d}^{-1}$, respectively (Fig. 2A,B). Corresponding values in the experiment with variable temperature and food availability were 5.0 and 0.18 eggs female $\mathrm{d}^{-1}$ (Fig. 2A,B). There were no significant differences in either EPR or SEPR between the incubations in ambient water and the $\mathrm{T} \times \mathrm{F}$ experiment (unpaired $t$-test, $p>0.05$ in all cases). In neither experiment were statistically significant correlations detected between EPR or SEPR and the prosome length of the females ( $p>0.05$ in all cases; Fig. 2A, $B_{\text {; }}$ size range $0.65 \pm$ $0.02 \mathrm{~mm}, \mathrm{n}=33$ ).

\section{Variability of RNA-DNA concentrations and RNA:DNA ratios}

In the incubations in ambient water, RNA and DNA concentrations averaged 79.5 and $25.6 \mu \mathrm{gg} \mathrm{C}^{-1}$ (Fig. 2C,D), respectively. In the $\mathrm{T} \times \mathrm{F}$ experiment, RNA and DNA concentrations averaged 73.9 and $24.0 \mu \mathrm{g} \mathrm{mg} \mathrm{C}^{-1}$, respectively (Fig. 2C,D). Corresponding RNA:DNA ratios varied from from 2.2 to 4.7 in ambient water and from 1.9 to 5.0 in the $\mathrm{T} \times \mathrm{F}$ experiment, with mean values of 3.0 and 3.1 , respectively (Fig. 2E). Although in all the experiments variability in DNA concentration was much lower than that of RNA and of RNA:DNA (Fig. 2C-E), the amount of DNA per individual varied to as high as 1.3-fold (0.027 to $0.035 \mu \mathrm{g})$. Neither nucleic acid concentrations nor their ratios differed significantly between the experiments with ambient water and the $\mathrm{T} \times \mathrm{F}$ experiments 

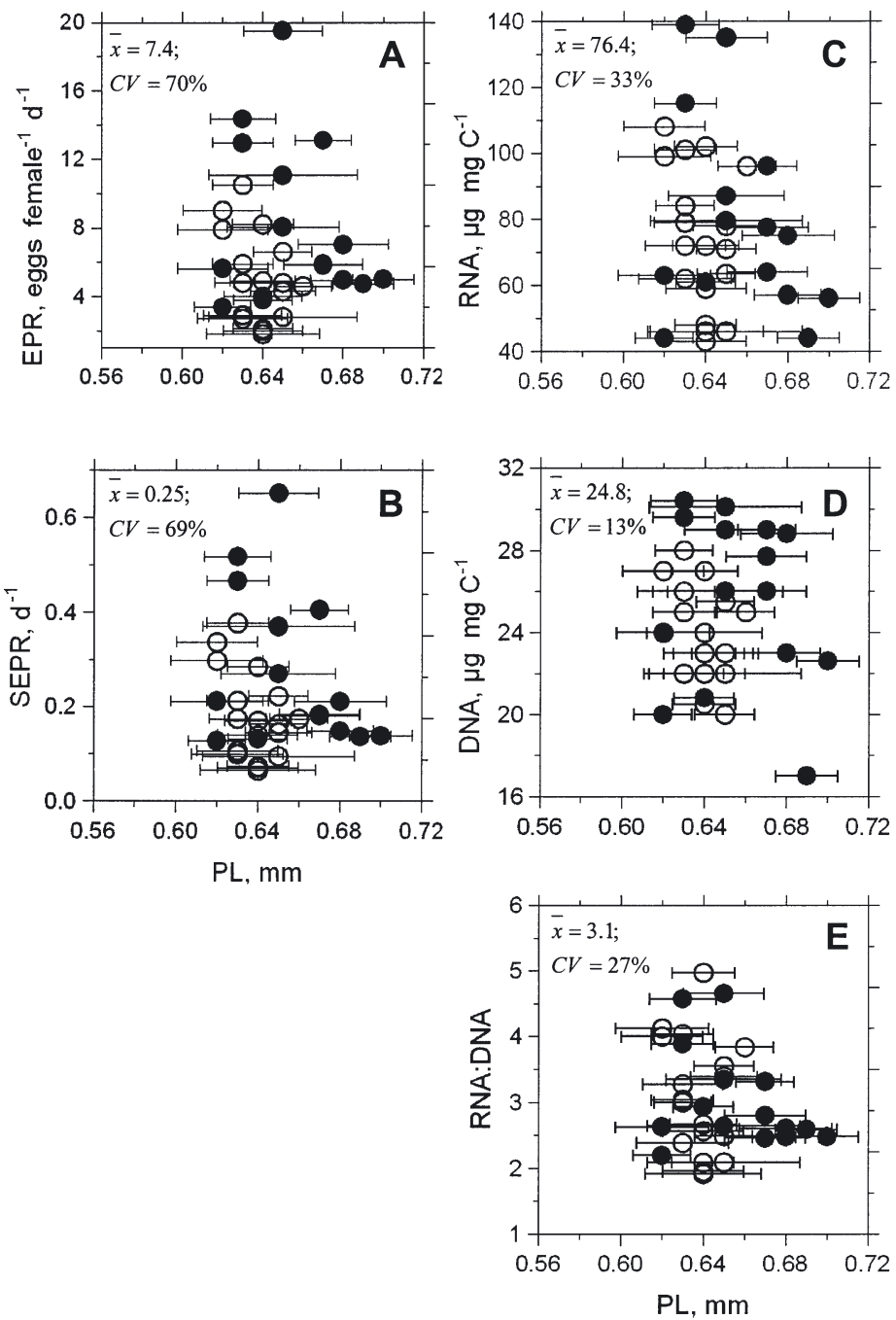

Fig. 2. Acartia bifilosa. (A) Egg production rates (EPR, eggs female $\left.\mathrm{e}^{-1} \mathrm{~d}^{-1}\right)$, (B) weight-specific egg production (SEPR, $\left.\mathrm{d}^{-1}\right)$,

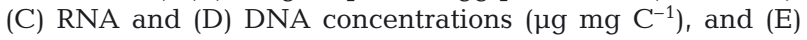
RNA:DNA ratio in relation to female prosome length (PL, $\mathrm{mm}$; mean $\pm \mathrm{SD}$ ). Open and closed symbols represent data from the $\mathrm{T} \times \mathrm{F}$ experiment and from incubations in ambient water, respectively. For each variable, the average value and coefficient of variation for the pooled data set are shown in the upper left corner of the graph

(unpaired $t$-test, $\mathrm{p}>0.05$ in all cases). In neither of the experiments were statistically significant correlations detected between RNA-DNA concentrations or RNA:DNA ratios and prosome length $(\mathrm{p}>0.05$ in all cases; Fig. 2C-E).

\section{Effects of temperature and food availability}

Variation in temperature and feeding conditions resulted in substantially different female growth rates (Table 1, Fig. 3). A 2-way ANOVA, with feeding regime and temperature as factors, and SEPR, RNA and DNA concentrations and RNA:DNA ratios as response variables, revealed highly significant effects of food levels on weight-specific fecundity, RNA concentration and RNA:DNA ratios (Table 1, Fig. 3A,C). At all food levels, both growth rates, RNA concentrations and RNA:DNA ratios appeared to be somewhat higher at 16 than at $9^{\circ} \mathrm{C}$ (Fig. 3A,C), but the differences were never significant (Table 1). There was a significant temperature effect, but also a significant interaction between temperature and food level in relation to DNA values (Table 1), suggesting that their effects on DNA concentration are complex. Simple-effect ANOVAs were conducted as follow-up tests because of the significant interaction. The DNA levels of copepods at either temperature did not differ significantly between the food levels (1-way ANOVA, p > 0.2 in both cases). However, while at low and medium food concentrations there were no significant differences between the temperatures (unpaired $t$-test, $\mathrm{p}>0.6$ in both cases), at high food levels, DNA values were significantly higher at 9 than at $16^{\circ} \mathrm{C}$ (unpaired $t$-test, $\mathrm{r}^{2}=0.81, \mathrm{p}<0.02$; Fig. 3B).

Table 1. Acartia bifilosa. 2-way ANOVAs, for weight-specific egg production (SEPR, $\mathrm{d}^{-1}$ ), RNA and DNA concentrations ( $\mu \mathrm{g} \mathrm{mg} \mathrm{C}^{-1}$ ) and the RNA:DNA ratio in females from the $\mathrm{T} \times \mathrm{F}$ experiment. Significant effects are indicated with asterisks $\left({ }^{*} \mathrm{p}<0.05,{ }^{* *} \mathrm{p}<0.01,{ }^{* * *} \mathrm{p}<0.001\right)$

\begin{tabular}{|lrccc|}
\hline $\begin{array}{l}\text { Variable, } \\
\text { Sources of variation }\end{array}$ & df & SS & MS & $F$ \\
\hline SEPR & & & & \\
$\quad$ Interaction & 2 & 0.00019 & 0.00010 & 0.05357 \\
$\quad$ Food & 2 & 0.1093 & 0.05488 & $30.25^{* * *}$ \\
$\quad$ Temperature & 1 & 0.00211 & 0.00211 & 1.170 \\
Error & 12 & 0.02169 & 0.00181 & \\
& & & & \\
RNA & & & & \\
Interaction & 2 & 194.3 & 97.16 & 2.905 \\
Food & 2 & 5464 & 2732 & $81.68^{* * *}$ \\
Temperature & 1 & 1.531 & 1.531 & 0.04578 \\
Error & 12 & 401.4 & 33.45 & \\
& & & & \\
DNA & & & & \\
Interaction & 2 & 21.28 & 10.64 & $3.994^{*}$ \\
Food & 2 & 1.440 & 0.7200 & 0.2703 \\
Temperature & 1 & 20.48 & 20.48 & $7.688^{*}$ \\
Error & 12 & 31.97 & 2.664 & \\
RNA:DNA & & & & \\
Interaction & 2 & 0.4416 & 0.2208 & 1.337 \\
Food & 2 & 9.044 & 4.522 & $27.37^{* * *}$ \\
Temperature & 1 & 0.09480 & 0.09480 & 0.5739 \\
Error & 12 & 1.982 & 0.1652 & \\
\hline
\end{tabular}



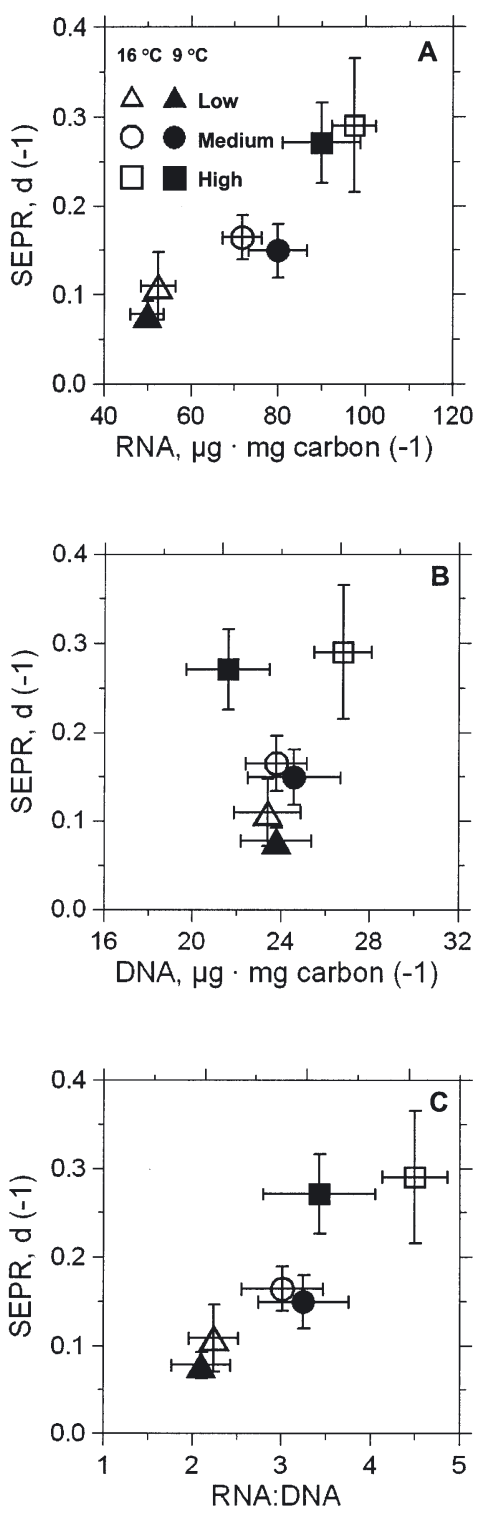

Fig. 3. Acartia bifilosa. $\mathrm{T} \times \mathrm{F}$ experiment: relationship between weight-specific egg production (SEPR, $\mathrm{d}^{-1}$ ) and (A) RNA and (B) DNA concentration ( $\left.\mu \mathrm{g} \mathrm{mg} \mathrm{C}^{-1}\right)$, and (C) RNA:DNA ratios in females incubated at 2 different temperatures $\left(9^{\circ} \mathrm{C}\right.$ : closed symbols; $16^{\circ} \mathrm{C}$ : open symbols) and 3 food levels (low, medium and high)

\section{RNA-DNA concentrations, RNA:DNA ratios and egg production rates}

There were significant positive relationships between female egg production rates and nucleic acid levels, as well as between egg production and RNA: DNA ratios for individuals incubated at both ambient conditions and in the $\mathrm{T} \times \mathrm{F}$ experiment (Table 2, Fig. 4). Because neither the slopes nor intercepts differed significantly between the regression lines for any of the conditions tested, the data were pooled for fitting common regression lines for RNA, DNA and the RNA:DNA ratio. As a result, not only RNA and the RNA:DNA ratio, but also DNA concentrations became significantly correlated with weight-specific egg production (Table 2, Fig. 4). The regressions between SEPR and RNA and between SEPR and the RNA:DNA ratio explained 92 and $75 \%$, respectively, while regression between SEPR and DNA explained only $42 \%$ of the total variance. Since DNA concentration was found to be affected by temperature at the high food levels (Table 1), data obtained at $16^{\circ} \mathrm{C}$ in the $\mathrm{T} \times \mathrm{F}$ experiment were combined with field measurements conducted at similar ambient temperatures, and corresponding regressions were calculated for SEPR-DNA and the SEPR-RNA:DNA ratio relationships (Table 2). By doing so, these relationships were strengthened: 80 and $77 \%$ of the total variance in SEPR was now explained by variations in DNA concentration and the RNA:DNA ratio, respectively. Still, the RNA concentration, which explained 88 to $95 \%$ of the total variance in SEPR (Table 2), and had narrower confidence limits of the regression line (Fig. 4A), was the best predictor of female production rates.

\section{DISCUSSION}

Relationships between the RNA content and/or the RNA:DNA ratio and growth rate have been demonstrated for a variety of aquatic metazoans (see Elser et al. 2000 for a summary), including copepods at different ontogenetic stages, i.e. females of Acartia grani (Saiz et al. 1998) and, more recently, juvenile stages of Calanus finmarchicus (Wagner et al. 2001). In this study, I demonstrate a similar relationship in females of $A$. bifilosa under summer temperatures and feeding conditions. This allows RNA-based growth indices to be used in the prediction of egg production rates in copepods. In particular, the regressions derived here can be used to assess the in situ reproductive growth of $A$. bifilosa under environmental conditions comparable to those observed during this study. Furthermore, since A. bifilosa is a common species for temperate waters and estuaries, this study provides a data set illustrating trends that might apply to other copepods with similar ecological preferences.

Because of high wind-induced mixing and thermocline erosion, environmental conditions during the study period were rather unusual: the maximum surface temperature approached the long-term mean and was the lowest observed in 6 previous years in the eastern Gotland basin (HELCOM 2002). Nevertheless, the ranges in egg production and body size were similar to those found for this species in other studies conducted during summer seasons in the Baltic (Schmidt 
Table 2. Acartia bifilosa. Statistics and parameter estimates of weight-specific egg production rate $\left(\mathrm{SEPR}, \mathrm{d}^{-1}\right)$ regressions on RNA-DNA concentrations ( $\mu \mathrm{g} \mathrm{mg} \mathrm{C}^{-1}$ ) and RNA:DNA ratios for field-collected females (oo, field), for females used in $\mathrm{T} \times \mathrm{F}$ experiment $\left(\right.$ o $_{\mathrm{O}}, \mathrm{T} \times \mathrm{F}$ ), for all the experiments $(\% \circ$, all data), and for data obtained at $16^{\circ} \mathrm{C}$ in $\mathrm{T} \times \mathrm{F}$ experiment combined with field measurements conducted at similar ambient temperatures (oo, ambient $\mathrm{T}^{\circ} \mathrm{C}$ ). In no case was significant deviation from linearity in the slope found. ns: $p>0.05$,

$$
{ }^{*} \mathrm{p}<0.05,{ }^{* *} \mathrm{p}<0.01,{ }^{* * *} \mathrm{p}<0.001
$$

\begin{tabular}{|c|c|c|c|c|c|}
\hline $\begin{array}{l}\text { Independent variables } \\
\text { and experimental groups } \\
\text { included in regression }\end{array}$ & Slope & Intercept & $r^{2}$ & $\begin{array}{c}\text { Significance } \\
F_{\mathrm{df}}\end{array}$ & $\begin{array}{l}\text { slope } \\
\mathrm{p}\end{array}$ \\
\hline \multicolumn{6}{|l|}{ RNA } \\
\hline 우, field & 0.0040 & -0.082 & 0.95 & $99.62_{1,2}$ & $* *$ \\
\hline 웅, $\mathrm{T} \times \mathrm{F}$ & 0.0042 & -0.134 & 0.88 & $31.59_{1,4}$ & $* *$ \\
\hline oq, all data & 0.0043 & -0.125 & 0.92 & $94.14_{1,8}^{1,4}$ & ${ }^{* * *}$ \\
\hline \multicolumn{6}{|l|}{ DNA } \\
\hline oฺ, field & 0.034 & -0.645 & 0.75 & $6.007_{1,2}$ & ns \\
\hline 우우, $\mathrm{T} \times \mathrm{F}$ & 0.003 & -0.110 & 0.01 & $0.0116_{1,4}$ & ns \\
\hline ơo, all data & 0.027 & -0.471 & 0.42 & $5.832_{1,8}^{1,4}$ & $*$ \\
\hline 우, ambient $\mathrm{T}^{\circ} \mathrm{C}$ & 0.038 & -0.739 & 0.80 & $20.61_{1,5}^{1,0}$ & ** \\
\hline \multicolumn{6}{|l|}{ RNA:DNA } \\
\hline op, field & 0.154 & -0.217 & 0.93 & $93.06_{1,2}$ & * \\
\hline 위, $\mathrm{T} \times \mathrm{F}$ & 0.090 & -0.103 & 0.82 & $18.74_{1,4}^{1,2}$ & * \\
\hline ㅇ, all data & 0.116 & -0.152 & 0.75 & $24.16_{1,8}$ & $* *$ \\
\hline фo, ambient $\mathrm{T}^{\circ} \mathrm{C}$ & 0.112 & -0.131 & 0.77 & $15.99_{1,5}$ & * \\
\hline
\end{tabular}

et al. 1998, Koski \& Kuosa 1999), as well as in other temperate estuaries (Uriarte et al. 1998, Burdloff et al. 2002). However, significant seasonal and geographical variations in all of these variables have been observed for Acartia bifilosa in the Baltic Sea (Viitasalo et al. 1995). Therefore, there remains a need to confirm that growth-RNA relationships exist in individuals with different life histories under various seasonal and trophic conditions, and a need to describe these relationships. In particular, contradictory results have been presented on the importance of female size for egg production in copepods (Peterson et al. 1991), and virtually nothing is known about variations in weight-specific quantities of nucleic acids and their ratios as a function of within-stage body size. Although in my study none of the variables were found to correlate significantly with body length (Fig. 2), this may not be the case over a wider size range. It would be desirable to carry out a study similar to the one presented here during a spring season, when the $A$. bifilosa population consists mostly of large, overwintered females (Viitasalo et al. 1995) adapted to low temperatures and low food concentrations from the winter period. Such individuals might have different physiological and metabolic rates than the summer generation, which consists of small-sized individuals (Viitasalo et al. 1995; this study) adapted to higher temperatures and moderate-to-high feeding conditions. The differences in morphology and life history may result in different growth patterns, metabolic rates, cell biochemistry, and altered relationships between growth and nucleic acid levels, as found for Calanus (Wagner et al. 2001, Hansen et al. 2003).

If considered separately, both temperature and food availability can affect growth and egg production of Acartia bifilosa (Uye 1981, Saiz et al. 1997, Koski \& Kuosa 1999). Several studies, however, indicate that temperature is a more important factor than food on a seasonal scale, while food conditions modulate egg-production dynamics mainly at shorter time scales (Uye 1981, White \& Roman 1992). Moreover, as indicated previously, a significant interactive effect of temperature on the RNA-EPR relationship has been found in A. grani (Saiz et al. 1998). In my study, the response to increased food levels was clearly pronounced, while the response to temperature was not (Table 1, Fig. 3). In the $\mathrm{T} \times \mathrm{F}$ experiment, egg production responding to increased food availability was similar to the generally observed functional response of A. bifilosa egg production, with the average egg production increasing up to chl a levels of $\sim 12 \mathrm{mg} \mathrm{m}^{-3}$ (Koski \& Kuosa 1999). Unexpectedly, SEPR estimates for individuals incubated in the ambient water shortly after collection covered a wider range than those in the $\mathrm{T} \times \mathrm{F}$ experiment (Figs. 2 \& 4). Moreover, maximal SEPR values of females incubated in media containing a 5-fold concentration of ambient seston assemblage were ca. $2 \times$ lower than those in the females collected from the mixing layer (Figs. 2 \& 4), where chl a values were nearly invariant. Several studies have shown that Acartia species prefer ciliates to phytoplankton, and their egg production is enhanced by ciliate feeding (Stoecker \& Sanders 1985, White \& Roman 1992). However, while preparing the food media for the $\mathrm{T} \times \mathrm{F}$ experiment, the ambient water was filtered to remove large colonies of phytoplankton, microzooplankton, and copepod eggs. As a result, ciliates were likely to become significantly reduced in the filtrate: due to their fragile nature, they easily burst when passing the sieve. Thus, a likely explanation to the larger variation and higher egg production rate in ambient water is that in the $\mathrm{T} \times \mathrm{F}$ experiment, the media was severely depleted in ciliates and had a lower food quality than the ambient plankton assemblage. This could potentially hamper egg production in the $\mathrm{T} \times \mathrm{F}$ experiment; the effect, however, was consistent among treatments and therefore did not affect the main result. Changes in both RNA and the 

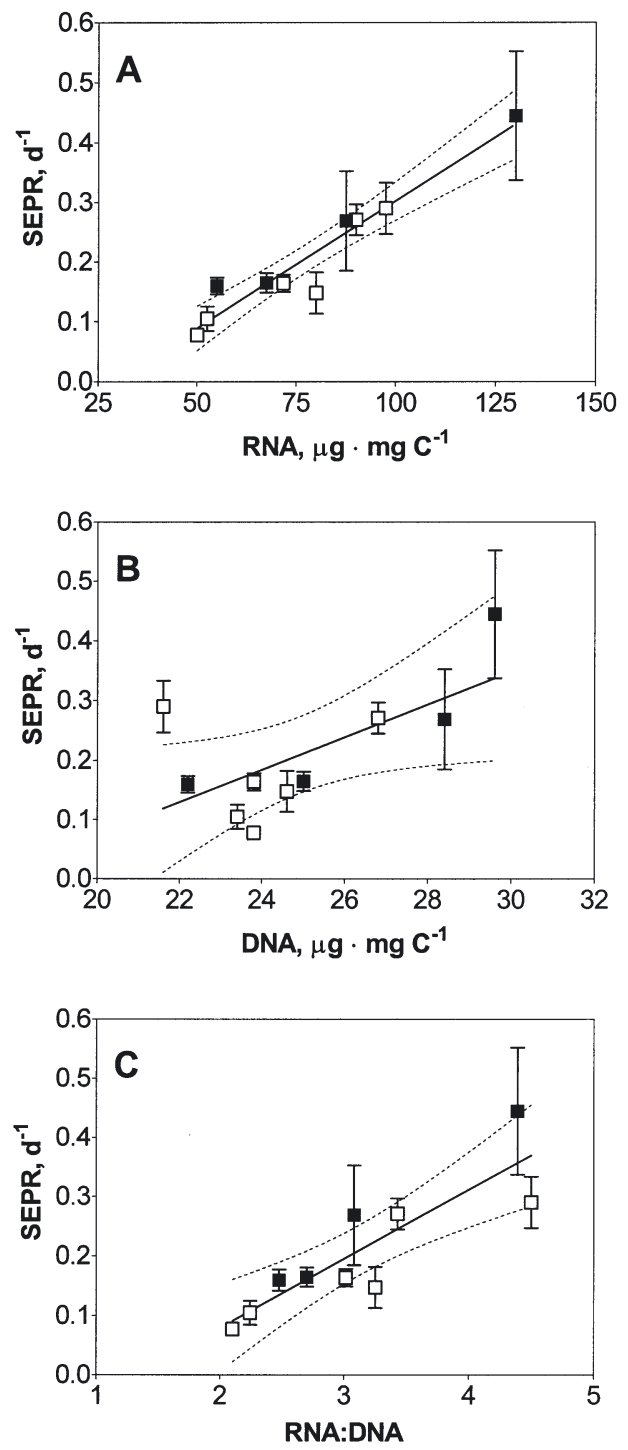

Fig. 4. Acartia bifilosa. Regressions between weight-specific egg production (SEPR, $\mathrm{d}^{-1}$ ) and (A) RNA and (B) DNA concentration ( $\mu \mathrm{g} \mathrm{mg} \mathrm{C}^{-1}$ ), and (C) RNA:DNA ratios from fieldcollected females (closed symbols) and those from the $\mathrm{T} \times \mathrm{F}$ experiment (open symbols). Each data point is a mean $\pm \mathrm{SD}$ of 3 to 5 replicates (see 'Materials and methods'). Solid lines are least-squares regressions; dotted lines show respective confidence intervals

RNA:DNA ratio were significantly correlated with changes in EPR and SEPR (Fig. 2, Table 2), and followed the same pattern. However, while both egg production rates and RNA-based indices in A. bifilosa strongly responded to variations in food abundance, they were virtually temperature-independent (Table 1) - at least during this time and in this area. This is in agreement with the results of Koski \& Kuosa (1999), who found no significant differences in egg production rate in the 7 to $18^{\circ} \mathrm{C}$ range in $A$. bifilosa from the sum- mer populations in the Gulf of Finland. It has also been suggested that the temperature optimum for this species in the Baltic spans the 6 to $16^{\circ} \mathrm{C}$ interval (Sidrevics 1980), indicating a high physiological plasticity. Furthermore, the lack of temperature-dependence is not unexpected, considering vertical distribution of the $A$. bifilosa population and the temperature conditions during the study period. According to our survey of vertical distribution of plankton during the cruise, up to $65 \%$ of older copepodites and adults stayed near the thermocline, where temperatures were around $10^{\circ} \mathrm{C}$, while the remaining part of the population occurred mostly in the upper waters with temperatures between 13 and $16^{\circ} \mathrm{C}$ (author's pers. obs.). Nevertheless, while the use of RNA-growth regression without a temperature variable is an empirical convenience, it may not hold over a wider temperature range; precise temperature functions would require more extensive experimental data.

Despite egg production not being directly related to temperature, there appears to be a change in growth response with temperature on a cellular level, as indicated by the DNA response. Copepods are known to exhibit determinate cell numbers (McLaren \& Marcogliese 1983); therefore, all adult females of the same species have a similar number of somatic cells after the last moult, regardless of their body size. Hence, given the facts that: (1) individual DNA content varied 1.3-fold between the analyzed females, (2) DNA concentrations correlated with growth rates (Fig. 4B), and (3) a combination of $16^{\circ} \mathrm{C}$ and the high food level in the $\mathrm{T} \times \mathrm{F}$ experiment resulted in a significantly higher DNA concentration in female bodies (Fig. 3B), the assumption of the invariant cellular DNA content in Acartia bifilosa, which is an important part of the rationale for using RNA:DNA ratio for growth assessment, has failed.

The intra-population and intra-individual variations in nuclear DNA content have been described for many plant and animal taxa (see review by Gregory \& Hebert 1999), including several calanoid species (McLaren et al. 1989, Escribano 1992). The DNA content of cells within an individual organism is believed to be manipulated in 2 ways. The first involves endopolyploidy and expansion of DNA in somatic cells; this process is especially common among arthropods (Lecher et al. 1995). The average proportion of polyploid nuclei in, for example, adult Daphnia pulex, was found to be as high as $27 \%$ (Korpelainen et al. 1997), or even close to $50 \%$, with ploidy levels varying among tissues from 2 to 2048 (Beaton \& Herbert 1999). Moreover, ploidy levels were affected by growth rate and age, with adults expressing more extensive polyploidy than juveniles (Beaton \& Herbert 1999). The second form of intra-individual DNA content modulation is chromatin diminution, when large amounts of DNA 
present in the zygote are deleted from early somatic cell lines (but not germline cells), resulting in gametic genomes that are substantially larger than expected from the somatic cell genome size (Gregory \& Hebert 1999). The chromatin diminution has been described for several species of copepods, and mature females and males showed many gonadal nuclei with elevated amounts of DNA, suggesting that cycles of DNA endoreduplication may occur in germ cells during gametogenesis (Wyngaard \& Rasch 2000). Genome size modulations may also result from the coordinate replication of some repetitive elements in the genome, in particular, those responsible for rRNA transcription and, therefore, potentially be related to protein synthesis and growth rates (White \& McLaren 2000, Gorokhova et al. 2002). Standiford (1988) suggested that during oogenesis in the copepod Acanthocyclops, when demand for rRNA is high, oocyte contains a large amount of extra rDNA sequences supplying all the rRNA needed by the embryo. Once oogenesis is complete, the extra rDNA sequences are then diminuted. Therefore, actively reproducing females are likely to have higher DNA levels. Indeed, recent studies have shown that in Calanus, ovarian cells undergoing oogenesis alter RNA:DNA ratios (Biegala et al. 1999). Thus, there are several possible explanations, none of them exclusive of one another, to account for the observed correlation between DNA concentration and growth rate in Acartia bifilosa (Table 2, Fig. 4B). However, regardless of the cause, the variable nuclear DNA content implies that for predicting growth rates, the RNA index is likely to be more reliable when the concentration is expressed per biomass unit rather than as RNA:DNA ratios. I found RNA concentration per carbon weight to have a higher predictive value than the RNA:DNA ratio, even when the regression SEPR-RNA:DNA was restricted to data obtained at similar temperatures (Table 2, Fig. 4). These findings agree with earlier studies that have shown RNA concentration per biomass unit to be a more sensitive indicator of nutritional condition than RNA:DNA ratios in lobsters (Parslow-Williams et al. 2001), shrimps (Moss 1994a,b), and fish (Ferguson \& Danzmann 1990).

One of the criticisms of using RNA-based indices as measures of growth rate has been that they may appear to correlate with growth rates purely as a function of ontogenetic change. It was suggested that a true test should include correlation analysis of nucleic acids and growth rates in individuals of the same size and/or developmental stage growing at different rates (Runge \& Roff 2000). This type of test was conducted in the present study and the results provide further evidence that RNA content does reflect reproductive growth rates in copepods, and may serve as a basis for in situ production assessment. Further experiments are, how- ever, needed (1) to establish similar relationships for juveniles of different developmental stages, as they are likely to be stage-specific (Wagner et al. 2001), and (2) to evaluate variations in growth-related life-history traits and their relationships with nucleic acid concentrations under varying environmental conditions.

Acknowledgements. I thank J. Walve, K. Török, and L. Lundgren (Systems Ecology, Stockholm University) for their help in collecting animals, providing chlorophyll and temperature data, conducting experiments and sharing their data on egg production. Thanks are also due to S. Hansson and U. Larsson (Systems Ecology) for their support, and to Prof. U. Lindberg (Cell Biology, Stockholm University) for his kind permission to use laboratory facilities. This study was financially supported by the Swedish Natural Science Research Council and the European Union through MAST/BASYS.

\section{LITERATURE CITED}

Adrian R, Hansson S, Sandin B, De Stasio B, Larsson U (1999) Effects of food availability and predation on a marine zooplankton community - a study on copepods in the Baltic Sea. Int Rev Hydrobiol 84:609-626

Båmsted U, Skjoldal HR (1980) RNA concentration of zooplankton: relationship with size and growth. Limnol Oceanogr 25:304-316

Beaton MJ, Herbert PDH (1999) Pattern of DNA synthesis and mitotic activity during the intermoult of Daphnia. J Exp Zool 268:400-409

Biegala IC, Harris RP, Bergeron JP (1999) ATCase activity, RNA:DNA ratio, gonad development stage, and egg production in the female copepod Calanus helgolandicus. Mar Biol 135:1-10

Burdloff D, Gasparini S, Villate F, Uriarte I, Cotano U, Sautour B, Etcheber H (2002) Egg production of the copepod Acartia bifilosa in two contrasting European estuaries in relation to seston composition. J Exp Mar Biol Ecol 274:1-17

Dagg MJ, Littlepage JL (1972) Relationship between growth rate and RNA, DNA, protein and dry weight in Artemia salina and Euchaeta elongata. Mar Biol 17:162-170

Elser J, Sterner R, Gorokhova E, Fagan W and 6 others (2000) Biological stoichiometry from genes to ecosystems. Ecol Lett 3:540-550

Escribano R, McLaren IA, Klein Breteler WC (1992) Innate and acquired variation in nuclear DNA contents of marine copepods. Genome 35:602-610

Ferguson M, Danzmann RG (1990) RNA:DNA ratios in white muscle as estimates of growth in rainbow trout held at different temperatures. Can J Zool 68:1494-1498

Gorokhova E, Kyle M (2002) Analysis of nucleic acids in Daphnia: development of methods and ontogenetic variations in RNA-DNA content. J Plankton Res 24:511-522

Gorokhova E, Dowling TE, Weider LJ, Crease TJ, Elser JJ (2002) Functional and ecological significance of rDNA IGS variation in a clonal organism under divergent selection for production rate. Proc R Soc Lond B 269:2373-2379

Gregory TR, Hebert PDN (1999) The modulation of DNA content: proximate causes and ultimate consequences. Genome Res 9:317-324

Hansen BW, Marker T, Andreassen P, Arashkewich E, Carlotti F, Lindeque P, Tande KS, Wagner M (2003) Differences in life-cycle traits of Calanus finmarchicus originating from $60^{\circ} \mathrm{N}$ and $69^{\circ} \mathrm{N}$, when reared in mesocosms at $69^{\circ}$ N. Mar Biol 142:877-893 
Hansson S, Larsson U, Johansson S (1990) Selective predation by herring and mysids, and zooplankton community structure in a Baltic Sea coastal area. J Plankton Res 12:1099-1116

HELCOM (1988) Guidelines for the Baltic Monitoring Programme for the third stage. Baltic Sea Environment Proceedings 27 D. Helsinki Commission, Helsinki, ISSN 0357-2994

HELCOM (2002) Environment of the Baltic Sea area 1994-1998. Baltic Sea Environment Proceedings 82 B. Helsinki Commission, Helsinki, ISSN 0357-2994

Juinio MA, Cobb JS, Bengtson D, Johnson M (1992) Changes in nucleic acids over the molt cycle in relation to food availability and to temperature in Homarus americanus postlarvae. Mar Biol 114:1-10

Kiørboe T, Sabatini M (1994) Reproductive and life-cycle strategies in egg-carrying cyclopoid and free-spawning calanoid copepods. J Plankton Res 16:1353-1366

Korpelainen H, Ketola M, Hietala J (1997) Somatic polyploidy examined by flow cytometry in Daphnia. J Plankton Res 19:2031-2040

Koski M, Kuosa H (1999) The effect of temperature, food concentration and female size on the egg production of the planktonic copepod Acartia bifilosa. J Plankton Res 21: 1779-1789

Laabir M, Poulet SA, Ianora A (1995) Measuring production and viability of eggs in Calanus helgolandicus. J Plankton Res 17:1125-1142

Lecher P, Defaye D, Noel P (1995) Chromosomes and nuclear DNA of Crustacea. Invertebr Reprod Dev 27:85-114

McLaren IA, Marcogliese SJ (1983) Similar nucleus numbers among copepods. Can J Zool 61:721-724

McLaren IA, Sévigny JM, Frost BW (1989) Evolutionary and ecological significance of genome sizes in copepod genus Pseudocalanus. Can J Zool 67:565-569

Miller CB, Huntley ME, Brooks ER (1984) Post-collection moulting rates of planktonic marine copepods: measurements, applications, problems. Limnol Oceanogr 29:1274-1289

Moltschaniwskyj NA, Jackson GD (2000) Growth and tissue composition as a function of feeding history in juvenile cephalopods. J Exp Mar Biol Ecol 253:229-241

Moss SM (1994a) Use of nucleic acids as indicators of growth in juvenile white shrimp, Penaeus vannamei. Mar Biol 120:359-367

Moss SM (1994b) Growth rates, nucleic acid concentrations, and RNA/DNA ratios of juvenile white shrimp, Penaeus vannamei Boone, fed different algal diets. J Exp Mar Biol Ecol 182:193-204

Nakata K, Nakano H, Kikuchi H (1994) Relationship between egg productivity and RNA/DNA ratio in Paracalanus sp. in the frontal waters of the Kurshio. Mar Biol 119:591-596

Olesen M, Andersson A, Gorokhova E, Hajdu S and 6 others (1999) Efficient recycling and low loss rates of nutrients from the Baltic Proper summer planktonic communityan effect of community structure? Third BASYS Annu Sci Conf, 20-22 September 1999, Warnemuende, Germany. Paper Abstracts: 27. Available at: www.io-warnemuende. de/public/bio/basys/con3/con3.htm

Ota AY, Landry MR (1984) Nucleic acids as growth rate indicators for early developmental stages of Calanus pacificus Brodsky. J Exp Mar Biol Ecol 80:147-160

Parslow-Williams PJ, Atkinson RJA, Taylor AC (2001) Nucleic acids as indicators of nutritional condition in the Norway lobster Nephrops norvegicus. Mar Ecol Prog Ser 211:235-243

Peterson WT, Tiselius P, Kiørboe T (1991) Copepod egg production, moulting and growth rates, and secondary production in the Skagerrak in August 1988. J Plankton Res 13:131-154

Editorial responsibility: Otto Kinne (Editor), Oldendorf/Luhe, Germany
Poulet SA, Ianora A, Laabir M, Klein Breteler WCM (1995) Towards the measurement of secondary production and recruitment in copepods. ICES J Mar Sci 52:359-368

Runge JA, Roff JC (2000) The measurement of growth and reproductive rates. In: Harris $\mathrm{R}$, Wiebe $\mathrm{P}$, Lenz J, Skjodal HR, Huntley M (eds) ICES zooplankton methodology manual. Academic Press, London, p 401-454

Saiz E, Calbet A, Trepat I, Irigoien X, Alcaraz M (1997) Food availability as a potential source of bias in the egg production method for copepods. J Plankton Res 19:1-14

Saiz E, Calbet A, Fara A, Berdalet E (1998) RNA content of copepods as a tool for determining adult growth rates in the field. Limnol Oceanogr 43:465-470

Schmidt K, Kähler P, von Bodungen B (1998) Copepod egg production rates in the Pomeranian Bay (Southern Baltic Sea) as a function of phytoplankton abundance and taxonomic composition. Mar Ecol Prog Ser 174:183-195

Sidreviks LL (1980) Investigations on the ecological characteristics of the main zooplankton species in the Central Baltic. In: Fisheries Investigations in the Basin of the Baltic Sea. Avots, Riga (in Russian)

Standiford DM (1988) The development of a large nucleolus during oogenesis in Acanthocyclops vernalis (Crustacea, Copepoda) and its possible relationship to chromatin diminution. Biol Cell 63:35-40

Stoecker DK, Sanders NK (1985) Differential grazing by Acartia tonsa on a dinoflagellate and a tintinnid. J Plankton Res $7: 85-100$

Sutcliffe WH (1965) Growth estimates from ribonucleic acid content in some small organisms. Limnol Oceanogr 10 (Suppl):R253-R258

Sutcliffe WH (1970) Relationship between growth rate and ribonucleic acid concentration in some invertebrates. J Fish Res Board Can 27:606-609

Uriarte I, Cotano U, Villate F (1998) Egg production of Acartia bifilosa in the small temperate estuary of Mundaka, Spain, in relation to environmental variables and population development. Mar Ecol Prog Ser 166:197-205

Uye SI (1981) Fecundity studies of neritic calanoid copepods Acartia clausi Giesbrecht and Acartia steueri Smirnov: a simple empirical model of daily egg production. J Exp Mar Biol Ecol 50:255-271

Viitasalo M (1992) Mesozooplankton of the Gulf of Finland and northern Baltic Proper-a review of monitoring data. Ophelia 35:147-168

Viitasalo M, Koski M, Pellikka K, Johansson S (1995) Seasonal and long-term variations in the body size of planktonic copepods in the northern Baltic Sea. Mar Biol 123:241-250

Vrede T, Persson J, Aronsen G (2002) The influence of food quality $(\mathrm{P}: \mathrm{C})$ ratio on RNA:DNA ratio and somatic growth rate of Daphnia. Limnol Oceanogr 47:487-494

Wagner M, Durbin E, Buckley L (1998) RNA:DNA ratios as indicators of nutritional condition in the copepod Calanus finmarchicus. Mar Ecol Prog Ser 162:173-181

Wagner MM, Campbell RG, Boudreau CA, Durbin EG (2001) Nucleic acids and growth of Calanus finmarchicus in the laboratory under different food and temperature conditions. Mar Ecol Prog Ser 221:185-197

White JR, Roman MR (1992) Egg production by the calanoid copepod Acartia tonsa in the mesohaline Chesapeake Bay: the importance of food resources and temperature. Mar Ecol Prog Ser 86:239-249

White MM, McLaren IA (2000) Copepod development rates in relation to genome size and 18S rDNA copy number. Genome 43:750-755

Wyngaard GA, Rasch EM (2000) Patterns of genome size in the Copepoda. Hydrobiologia 417:43-56

Submitted: April 8, 2003; Accepted: September 7, 2003

Proofs received from author(s): October 20, 2003 